\title{
PENGARUH PENAMBAHAN BEKATUL BERAS MERAH TERHADAP KANDUNGAN GIZI, AKTIVITAS ANTIOKSIDAN DAN KESUKAAN SOSIS TEMPE
}

\author{
Kadi Kusumastuti, Fitriyono Ayustaningwarno* \\ Program Studi Ilmu Gizi Fakultas Kedokteran Universitas Diponegoro \\ Jl.Dr.Sutomo No.14, Semarang, Telp (024) 8453708, Email : gizifk@undip.ac.id
}

\begin{abstract}
Background: Cardiovascular disease is a main cause of mortality in the world. Fiber and antioxidant are known could prevent this problem. Thus need the alternative food in which rich of fiber and antioxidant.

Objective: To determine effect of red rice bran addition to nutrient content, antioxidant activity, and preference of tempeh sausages.

Methods: Research type was randomized experimental study of the one factor design. Percentages of rice bran addition are 0\%, 2\%, 5\%, and 10\%. Statistic analysis by one way ANOVA followed by Tukey test

Results: The higher addition of red rice bran cause higher protein, fat, carbohydrate, fiber content and antioxidant activity of tempeh sausages. The highest protein, fat, carbohydrate, fiber content and antioxidant activity was tempeh sausage with $10 \%$ red rice bran addition. However, higher percentages of red rice bran addition make decreasing panelist preference of tempeh sausages.

Conclusions: There was no influence of red rice bran addition to nutrient content of tempeh sausages, but there was influence to antioxidant activity and panelist preference. Recommended sausages are sausages with $5 \%$ red rice bran addition. This sausages in 100 grams fulfilled 16,39\% protein of diet $2000 \mathrm{kkal}$, 33,65\% of 25 gr/d fiber needed, and antioxidant activity was $12,83 \%$.
\end{abstract}

Keyword: red rice bran; tempeh; sausages; nutrient content; antioxidant; preference

\begin{abstract}
ABSTRAK
Latar Belakang: Penyakit kardiovaskuler menduduki peringkat pertama penyebab kematian di dunia. Serat dan antioksidan diketahui dapat mencegah masalah ini. Oleh sebab itu, dibuat alternatif makanan yang kaya serat dan antioksidan.

Tujuan: Mengetahui pengaruh penambahan bekatul beras merah terhadap kandungan gizi, aktivitas antioksidan dan kesukaan sosis tempe.

Metode: Merupakan penelitian eksperimental dengan rancangan acak lengkap satu faktor, yaitu faktor perbedaan persentase penambahan bekatul beras merah pada sosis tempe. Persentase penambahan bekatul beras merah yaitu sebanyak 0\%, 2\%, 5\%, dan 10\%. Analisis statistik menggunakan uji ANOVA satu arah dilanjutkan dengan uji Tukey Hasil: Semakin besar persentase penambahan bekatul beras merah, kadar protein, lemak, karbohidrat, serat dan aktivitas antioksidan sosis tempe semakin meningkat. Kadar protein, lemak, karbohidrat, serat dan aktivitas antioksidan sosis tempe tertinggi terdapat pada sosis tempe dengan penambahan bekatul 10\%. Namun, semakin besar persentase penambahan bekatul beras merah, sosis tempe cenderung tidak disukai oleh panelis.

Kesimpulan: Tidak ada pengaruh penambahan bekatul beras merah terhadap kadar protein, karbohidrat, dan lemak sosis tempe, tetapi ada pengaruh terhadap aktivitas antioksidan dan mutu organoleptik sosis tempe. Sosis tempe yang direkomendasikan adalah sosis tempe dengan penambahan bekatul beras merah 5\% yang dapat memenuhi 16,39\% kecukupan protein dari diet 2000kkal, 33,65\% dari kebutuhan serat 25 gr/hari, serta mengandung aktivitas antioksidan 12,83\%.
\end{abstract}

Kata kunci: bekatul beras merah; tempe; sosis; kandungan gizi; antioksidan; kesukaan

\section{PENDAHULUAN}

Stres oksidatif merupakan peningkatan kadar radikal bebas dalam tubuh. Hal ini berhubungan dengan perkembangan penyakit kronik dan degeneratif, termasuk penyakit kardiovaskuler, kanker, dan degenerasi neural yang merupakan bagian dari proses penuaan. ${ }^{1}$ Penyakit kardiovaskuler menduduki peringkat pertama penyebab kematian di dunia pada tahun 2004 dengan prevalensi pada wanita sebesar $32 \%$ dan pria 27\%. World Health Organization (WHO) memprediksi jumlah kematian akibat penyakit kardiovaskuler di dunia akan meningkat dari 7,4 juta orang pada tahun 2004 menjadi 23,4 juta orang pada tahun $2030 .^{2}$

Salah satu upaya untuk mencegah dan mengatasi masalah kardiovaskuler adalah melalui pengaturan diet, yaitu mengurangi konsumsi lemak 
total dan lemak jenuh serta meningkatkan asupan serat. ${ }^{3}$ PERKI (Perhimpunan Kardiologi Indonesia) menyarankan konsumsi serat adalah 25-30 g/hari untuk kesehatan jantung dan pembuluh darah. ${ }^{4}$ Selain serat, antioksidan juga berperan dalam mengatasi masalah kardiovaskuler. Antioksidan merupakan zat yang dapat mencegah terjadinya reaksi oksidasi radikal bebas dalam oksidasi lemak. $^{1}$ Alternatif yang dapat dilakukan adalah meningkatkan asupan serat dan antioksidan pada jenis makanan yang populer di masyarakat. Salah satu makanan yang banyak dikonsumsi adalah sosis. $^{5}$

Sosis merupakan makanan dari daging yang digiling, dibumbui lalu dimasukkan ke dalam selongsong (casing) berbentuk bulat panjang simetris yang kemudian diolah lebih lanjut. ${ }^{6}$ Konsumsi sosis di Indonesia semakin meningkat. Pada tahun 1995, konsumsi sosis per kapita hanya mencapai 2,9 gram, kemudian terus meningkat hingga mencapai 53,3 gram per kapita per hari pada tahun $2000 .{ }^{5}$ Pada umumnya sosis dibuat dari daging sapi, daging ayam, daging babi, daging kelinci dan ikan. ${ }^{6}$ Daging banyak mengandung asam lemak jenuh yang bila dikonsumsi secara berlebihan akan menyebabkan penyumbatan pembuluh darah atau aterosklerosis. ${ }^{3}$ Oleh sebab itu, saat ini dikembangkan sosis dari bahan nabati yaitu tempe. $^{7}$

Tempe merupakan makanan olahan yang merupakan hasil fermentasi kedelai. Tempe mengandung serat, antioksidan, $60 \%$ asam lemak tidak jenuh (asam linoleat dan asam linolenat). ${ }^{8}$ Tempe termasuk ke dalam olahan kelompok legumes (kacang - kacangan) yang bila dipadukan dengan kelompok grains (biji - bijian) dapat menjadi kombinasi yang baik untuk mendapatkan asam - asam amino esensial yang lengkap. Hal ini disebabkan karena kedua jenis bahan makanan tersebut memiliki asam amino pembatas. Asam amino pembatas dalam tempe adalah asam amino metionin dan sistin, sedangkan pada biji-bijian adalah asam amino lisin. ${ }^{9}$ Salah satu bahan pangan yang berasal dari biji-bijian adalah beras merah. Hasil samping dari penggilingan beras merah adalah bekatul beras merah. ${ }^{10}$ Selama ini bekatul hanya dianggap sebagai limbah. Padahal bekatul memiliki kandungan serat pangan, protein, mineral, lemak tidak jenuh dan antioksidan. ${ }^{11}$

Berdasarkan latar belakang di atas, peneliti mengajukan alternatif untuk mengatasi masalah tersebut dengan sosis tempe dengan penambahan bekatul beras merah. Sosis merupakan merupakan produk emulsi. ${ }^{6}$ Berdasarkan penelitian Choi et al., penambahan bekatul dalam produk emulsi dapat meningkatkan stabilitas emulsi karena bekatul bersifat menyerap air. ${ }^{12}$ Oleh karena itu, dilakukan penelitian pembuatan sosis tempe dengan penambahan bekatul beras merah yang selanjutnya dilakukan analisis kandungan gizi, aktivitas antioksidan dan tingkat kesukaan.

\section{METODA}

Penelitian yang dilakukan merupakan penelitian dalam bidang Food Production. Penelitian dilakukan di Laboratorium Gizi Fakultas Ilmu Kesehatan Universitas Muhammadiyah Semarang dan Laboratorium Ilmu Pangan Fakultas Teknologi Pertanian UNIKA Soegijapranata Semarang pada bulan Juli hingga Agustus 2012.

Penelitian ini merupakan penelitian eksperimental dengan rancangan acak lengkap satu faktor, yaitu faktor perbedaan persentase penambahan bekatul beras merah pada sosis tempe. Persentase penambahan bekatul beras merah pada pembuatan sosis tempe yaitu sebanyak $0 \%$ (S0), 2\% (S1), 5\% (S2), dan 10\% (S3). Penetapan formulasi didasarkan pada penelitian pembuatan produk emulsi bakso bahwa penambahan bekatul kurang dari $10 \%$ menunjukkan tidak ada perbedaan kualitas sensori yang signifikan dengan bakso kontrol, sementara penambahan bekatul sebesar $15 \%$ menghasilkan kualitas sensori yang kurang baik. ${ }^{14}$ Penambahan bekatul sebesar $2 \%$ pada penelitian pembuatan sosis frankfurters menunjukkan kualitas sosis yang tidak berbeda dengan sosis kontrol. ${ }^{12}$ Selanjutnya setiap perlakuan dilakukan tiga kali pengulangan. Kemudian sosis tempe dengan persentase penambahan bekatul beras merah yang berbeda dianalisis kandungan gizi dan aktivitas antioksidan secara duplo, serta tingkat kesukaan dujikan pada 30 panelis dengan tiga kali pengulangan.

Sosis tempe merupakan makanan olahan yang dibuat dengan bahan utama tempe. Bahan pendukung dalam pembuatan sosis tempe antara lain tepung tapioka, minyak, putih telur, garam, gula, bumbu, es batu, dan bekatul beras merah. Tempe yang digunakan merupakan tempe kedelai murni dengan merk "Muchlar" yang didapatkan dari pasar di kota Yogyakarta dan bekatul beras merah didapatkan dari petani beras merah di Dusun Duwetsari, Padasan, Ds. Pakembinangun, Kecamatan Pakem, Sleman, Yogyakarta. Varietas yang digunakan adalah bekatul dari beras merah varietas lokal yaitu beras Cempo Merah. Bekatul yang akan digunakan diayak terlebih dahulu 
dengan ayakan 80 mesh untuk mendapatkan keseragaman ukuran.

Proses pembuatan sosis tempe adalah sebagai berikut, tempe dikukus terlebih dahulu selama 15 menit. Setelah dingin, tempe digiling bersama es batu, putih telur, tepung tapioka, garam, gula, bumbu, dan bekatul beras merah dalam food processor selama 1 menit. Selanjutnya ditambahkan minyak jagung dan digiling lagi selama 1 menit hingga menjadi adonan homogen. Adonan tersebut kemudian dimasukkan dalam stuffer untuk dimasukkan dalam selongsong sosis yang terbuat dari kolagen sapi. Setelah sosis diikat masing-masing $\pm 10 \mathrm{~cm}$, kemudian sosis dikukus sampai matang. ${ }^{15}$

Pada penelitian ini, data yang dikumpulkan yaitu kandungan gizi (protein, lemak, serat, karbohidrat), aktivitas antioksidan, dan tingkat kesukaan sosis tempe dengan berbagai persentase penambahan bekatul beras merah. Kadar protein diuji dengan metode Kjeldahl $^{13}$, kadar lemak diuji dengan metode Soxhlet ${ }^{13}$, kadar serat diuji dengan metode gravimetri ${ }^{13}$, kadar karbohidrat dihitung dengan perhitungan karbohidrat by difference ${ }^{13}$, aktivitas antioksidan diuji dengan metode DPPH (2,2 dhipenyl -1-pycrilhidrazyil $)^{16}$. Kesukaan warna, aroma, tekstur, dan rasa diujikan menggunakan uji hedonik pada panelis agak terlatih dari mahasiswa Program Studi Ilmu Gizi Universitas Diponegoro dengan kriteria penilaian 1 = sangat tidak suka, 2 = tidak suka, $3=$ netral, $4=$ suka, 5 = sangat suka.

Pengaruh penambahan bekatul beras merah terhadap kandungan gizi, aktivitas antoksidan dan mutu organoleptik dianalisis dengan uji statistik ANOVA (Analysis of Varians) satu arah. Selanjutnya dilakukan uji lanjut Multiple Comparation (posthoc test) dengan uji Tukey untuk mengetahui beda nyata antar perlakuan. Sementara itu, data tingkat kesukaan menggunakan uji Friedman dan uji lanjut Wilcoxon.

\section{HASIL \\ 1. Kandungan Gizi Sosis Tempe dengan Penambahan Bekatul Beras Merah}

Tabel 1. Rerata Kandungan Gizi Sosis Tempe dengan Penambahan Bekatul Beras

\begin{tabular}{ccccc} 
Jenis & Merah \\
Perlakuan & $\begin{array}{c}\text { Rerata Kadar } \\
\text { Protein (\% berat } \\
\text { basah) }\end{array}$ & $\begin{array}{c}\text { Rerata Kadar } \\
\text { Lemak } \\
(\% \text { berat basah })\end{array}$ & $\begin{array}{c}\text { Rerata Kadar } \\
\text { Karbohidrat } \\
(\% \text { berat } \\
\text { basah })\end{array}$ & $\begin{array}{c}\text { Rerata Kadar } \\
\text { Serat } \\
(\% \text { berat } \\
\text { basah })\end{array}$ \\
\hline S0 & $12.008 \pm 0.18$ & $19.498 \pm 0.20$ & $13.814 \pm 0.98$ & $6.282 \pm 0.95$ \\
S1 & $12.512 \pm 1.13$ & $20.155 \pm 2.09$ & $18.522 \pm 2.66$ & $7.184 \pm 0.50$ \\
S2 & $12.689 \pm 1.28$ & $20.218 \pm 1.16$ & $18.725 \pm 2.45$ & $8.413 \pm 1.34$ \\
S3 & $12.850 \pm 0.16$ & $20.469 \pm 1.68$ & $19.005 \pm 1.75$ & $9.138 \pm 1.26$ \\
\hline & $\mathbf{p = 0 . 6 7 0}$ & $\mathbf{p = 0 . 8 6 6}$ & $\mathbf{p = 0 . 0 9 9}$ & $\mathbf{p = 0 . 0 8 2}$ \\
\hline
\end{tabular}

Terdapat peningkatan hasil analisa kadar protein, lemak, karbohidrat, dan serat sosis tempe secara linier. Semakin banyak penambahan bekatul beras merah, kandungan gizi sosis tempe cenderung meningkat. Kadar protein, lemak, karbohidrat, dan serat tertinggi terdapat pada sosis tempe dengan penambahan bekatul beras merah $10 \%$. Kadar protein pada sosis tempe dengan penambahan bekatul beras merah $10 \%$ yaitu $12,85 \%$, kadar lemak yaitu $20,47 \%$, kadar karbohidrat yaitu $19 \%$, dan kadar serat yaitu $9,14 \%$.
Kadar protein, lemak, karbohidrat, dan serat terendah terdapat pada sosis tempe kontrol. Kadar protein pada sosis tempe kontrol yaitu $12,01 \%$, kadar lemak yaitu $19,50 \%$, kadar karbohidrat yaitu $13,81 \%$, dan kadar serat yaitu $6,23 \%$. Namun secara statistik penambahan bekatul beras merah tidak berpengaruh secara signifikan terhadap kadar protein, lemak, karbohidrat dan serat sosis tempe.

\section{Aktivitas Antioksidan Sosis Tempe dengan} Penambahan Bekatul Beras Merah 
Tabel 2. Rerata Aktivitas Antioksidan Sosis Tempe dengan Penambahan Bekatul Beras Merah

\begin{tabular}{cc}
\hline Jenis Perlakuan & $\begin{array}{c}\text { Rerata Aktivitas Antioksidan } \\
(\% \text { discoloration })\end{array}$ \\
\hline S0 & $7.975 \pm 0.59^{\mathrm{a}}$ \\
S1 & $9.506 \pm 0.32^{\mathrm{ab}}$ \\
S2 & $12.829 \pm 2.72^{\mathrm{bc}}$ \\
S3 & $13.285 \pm 0.39^{\mathrm{c}}$ \\
\hline & $\mathbf{p = 0 . 0 0 4 ^ { * }}$ \\
\hline
\end{tabular}

Aktivitas antioksidan tertinggi terdapat pada sosis tempe dengan penambahan bekatul beras merah $10 \%$, yaitu $13,28 \%$ dan aktivitas antioksidan terendah terdapat pada sosis tempe kontrol, yaitu $7,97 \%$. Semakin banyak penambahan bekatul beras merah, maka aktivitas antioksidan sosis tempe cenderung meningkat. Penambahan bekatul beras merah mempengaruhi aktivitas antioksidan sosis tempe.

3. Kesukaan Sosis Tempe dengan Penambahan Bekatul Beras Merah

Tabel 3. Rerata kesukaan warna, aroma, tekstur, dan rasa Sosis Tempe dengan Penambahan Bekatul Beras Merah

\begin{tabular}{|c|c|c|c|c|c|c|c|c|}
\hline \multirow{2}{*}{$\begin{array}{c}\text { Perlakua } \\
\text { n }\end{array}$} & \multicolumn{2}{|l|}{ Warna } & \multicolumn{2}{|l|}{ Aroma } & \multicolumn{2}{|l|}{ Tekstur } & \multicolumn{2}{|l|}{ Rasa } \\
\hline & Rerata & Ket. & Rerata & Ket. & Rerata & Ket. & Rerata & Ket. \\
\hline S0 & $\begin{array}{c}3.84 \pm \\
0.73^{\mathrm{a}}\end{array}$ & Suka & $\begin{array}{c}3.46 \pm \\
0.69^{\mathrm{a}}\end{array}$ & $\begin{array}{c}\text { Netra } \\
1\end{array}$ & $\begin{array}{c}3.48 \pm \\
0.77^{\mathrm{a}}\end{array}$ & $\begin{array}{c}\text { Netra } \\
1\end{array}$ & $\begin{array}{c}3.51 \\
\pm 0.88^{\mathrm{a}}\end{array}$ & Suka \\
\hline S1 & $\begin{array}{c}3.26 \pm \\
0.79^{\mathrm{b}}\end{array}$ & $\begin{array}{c}\text { Netra } \\
1\end{array}$ & $\begin{array}{c}3.18 \pm \\
0.89^{\mathrm{b}}\end{array}$ & $\begin{array}{c}\text { Netra } \\
1\end{array}$ & $\begin{array}{c}3.46 \\
\pm 0.77^{\mathrm{a}}\end{array}$ & $\begin{array}{c}\text { Netra } \\
1\end{array}$ & $\begin{array}{c}3.38 \\
\pm 0.82^{\mathrm{a}}\end{array}$ & $\begin{array}{c}\text { Netra } \\
1\end{array}$ \\
\hline S2 & $\begin{array}{l}2.69 \pm \\
0.86^{\mathrm{c}}\end{array}$ & $\begin{array}{c}\text { Netra } \\
1\end{array}$ & $2.83 \pm 0.84^{\mathrm{c}}$ & $\begin{array}{c}\text { Netra } \\
1\end{array}$ & $\begin{array}{c}3.24 \\
\pm 0.77^{\mathrm{b}}\end{array}$ & $\begin{array}{c}\text { Netra } \\
1\end{array}$ & $\begin{array}{c}2.94 \\
\pm 0.94^{\mathrm{b}}\end{array}$ & $\begin{array}{c}\text { Netra } \\
1\end{array}$ \\
\hline S3 & $\begin{array}{l}2.09 \pm \\
0.87^{\mathrm{d}}\end{array}$ & $\begin{array}{c}\text { Tida } \\
\text { k } \\
\text { Suka }\end{array}$ & $\begin{array}{l}2.63 \pm \\
0.83^{\mathrm{d}}\end{array}$ & $\begin{array}{c}\text { Netra } \\
1\end{array}$ & $\begin{array}{c}3.04 \\
\pm 0.83^{\mathrm{c}}\end{array}$ & $\begin{array}{c}\text { Netra } \\
1\end{array}$ & $\begin{array}{c}2.54 \\
\pm 0.88^{\mathrm{c}}\end{array}$ & $\begin{array}{c}\text { Tida } \\
\text { k } \\
\text { Suka }\end{array}$ \\
\hline & $p=0.000$ & & $p=0.000$ & & $p=0.000$ & & $p=0.00$ & \\
\hline
\end{tabular}

Tabel 3. menunjukkan bahwa kesukaan panelis terhadap warna, aroma, rasa dan tekstur tertinggi terdapat pada sosis tempe kontrol. Skor kesukaan warna sosis tempe kontrol yaitu 3,84 (suka), skor kesukaan aroma yaitu 3,46 (netral), skor kesukaan tekstur yaitu 3,48 (netral),dan skor kesukaan rasa yaitu 3,51 (suka).

Kesukaan panelis terhadap warna, aroma, rasa dan tekstur terendah terdapat pada sosis tempe dengan penambahan bekatul beras merah $10 \%$. Skor kesukaan warna sosis tempe dengan penambahan bekatul beras merah $10 \%$ yaitu 2,09 (tidak suka), skor kesukaan aroma yaitu 2,63 (netral), skor kesukaan tekstur yaitu 3,04 (netral), dan skor kesukaan rasa yaitu 2,54 (tidak suka).

Penambahan bekatul beras merah yang semakin banyak menyebabkan sosis tempe cenderung tidak disukai panelis. Secara statistik ada pengaruh persentase penambahan bekatul beras merah terhadap kesukaan panelis akan warna, aroma, tekstur, dan rasa sosis tempe.

\section{PEMBAHASAN}

Pengaruh Penambahan Bekatul Beras Merah terhadap Kandungan Gizi Sosis Tempe

1. Kadar Protein

Penambahan bekatul beras merah tidak berpengaruh secara signifikan terhadap perubahan kadar protein dalam sosis tempe. Hal ini dapat disebabkan karena jumlah penambahan bekatul beras merah yang tidak terlalu banyak dalam sosis tempe. Kadar protein sosis tempe tergantung pada kadar protein yang terkandung dalam tempe sebagai bahan utamanya dan bekatul beras merah yang 
ditambahkan. Kedua bahan makanan tersebut merupakan bahan makanan yang mengandung protein. Kandungan protein dalam tempe sebesar $46,5 \%{ }^{17}$ Sementara bekatul beras merah mengandung protein sebesar $11,2 \%{ }^{18}$

Kombinasi kedua bahan makanan tersebut menyumbang peningkatan kadar protein dalam sosis dan memberikan efek komplementari asam amino essensial. Kedua bahan makanan ini memiliki asam amino pembatas. Asam amino pembatas dalam kacang-kacangan adalah asam amino metionin dan sistin, sedangkan dalam serealia adalah asam amino esensial lisin. ${ }^{9}$ Berdasarkan perhitungan dari data sekunder, asam amino esensial lisin dan metionin dalam sosis tempe meningkat dan bukan menjadi asam amino pembatas. Namun, asam amino esensial sistin masih menjadi asam amino pembatas. Perhitungan kandungan asam amino essensial dapat dilihat di Lampiran 3.

Protein dalam pembuatan sosis berperan sebagai penstabil emulsi. Protein berperan dalam ikatan air dan minyak dalam sistem emulsi. Hal ini disebabkan karena protein memiliki sifat hidrofilik dan hidrofobik. ${ }^{19}$ Oleh sebab itu, dalam pembuatan sosis, suhu selama penggilingan harus dikontrol agar tidak lebih dari $22^{\circ} \mathrm{C}$ untuk menghindari kerusakan protein yaitu dengan penambahan es sekitar $15-30 \%$ dari berat bahan. ${ }^{6}$

\section{Kadar Lemak}

Berdasarkan hasil penelitian, penambahan bekatul beras merah tidak signifikan berpengaruh terhadap perubahan kadar lemak dalam sosis tempe. Hal ini dapat disebabkan karena jumlah minyak jagung yang ditambahkan dalam setiap perlakuan dalam jumlah yang sama. Perbedaan antar perlakuan terletak pada jumlah bekatul beras merah yang ditambahkan. Kandungan lemak dalam bekatul beras merah adalah $11,2 \mathrm{~g} / 100 \mathrm{~g}$ bahan. ${ }^{18}$ Jumlah penambahan bekatul beras merah tidak terlalu banyak sehingga perubahan kadar lemak menjadi tidak signifikan.

Lemak dalam sosis berasal dari lemak yang terkandung dalam tempe, bekatul beras merah, dan minyak jagung. Penambahan minyak/lemak dalam pembuatan sosis bertujuan untuk membentuk tekstur sosis yang kompak dan memperbaiki cita rasa. ${ }^{6}$ Lemak dalam produk sosis juga berperan dalam membentuk emulsi yang stabil dan mengurangi penyusutan dalam pemasakan. ${ }^{12}$
Minyak jagung mengandung asam lemak tidak jenuh. Asam lemak yang dominan dalam minyak jagung adalah oleat $(36,99 \%)$ dan linoleat $(47,19 \%) .^{20}$ Berdasarkan penelitian Choi, et.al, sosis frankfurters yang menggunakan minyak sayur memiliki kadar kolesterol 45-50\% lebih rendah dibandingkan sosis tanpa minyak sayur. ${ }^{12}$ American Heart Association (AHA) merekomendasikan perubahan diet dapat menurunkan risiko penyakit kardiovaskuler, yaitu konsumsi asam lemak jenuh kurang dari 7\% dari kebutuhan kalori dan asupan lemak total sekitar 25-35\% dari kebutuhan kalori. ${ }^{3}$

\section{Kadar Karbohidrat}

Berdasarkan perhitungan statistik, diketahui bahwa tidak ada pengaruh penambahan bekatul beras merah terhadap kadar karbohidrat sosis tempe. Hal ini dapat dipengaruhi oleh tepung tapioka yang ditambahkan dalam seluruh perlakuan dengan jumlah yang sama dan penambahan bekatul beras merah yang tidak berbeda terlalu banyak.

Bahan yang menyumbang karbohidrat dalam sosis tempe adalah tepung tapioka. Penambahan tepung dalam pembuatan sosis bertujuan untuk meningkatkan kualitas sosis dengan berperan sebagai pengikat, membentuk gel, dan membentuk tekstur sosis. Penelitian Rosjarin menyebutkan bahwa penambahan $7 \%$ tepung tapioka dalam produk sosis dapat meningkatkan kapasitas pengikatan air dan mengurangi penyusutan dalam pemasakan. ${ }^{21}$

\section{Kadar Serat}

Berdasarkan hasil penelitian, penambahan bekatul beras merah secara statistik tidak mempengaruhi peningkatan kadar serat kasar sosis tempe. Hal ini dapat disebabkan karena persentase penambahan bekatul beras merah yang terlalu sedikit antar perlakuan. Namun, kombinasi tempe dan bekatul beras merah memiliki kontribusi dalam meningkatkan kandungan serat dalam makanan. Tempe merupakan bahan makanan hasil olahan kacang-kacangan yang mengandung serat $7,2 \%,{ }^{17}$ sedangkan bekatul beras merah mengandung serat $42,91 \% .{ }^{18}$

Penambahan serat dalam produk emulsi mempengaruhi kestabilan emulsi. Penelitian menyebutkan bahwa penambahan serat pektin dalam pembuatan margarin menghasilkan produk dengan emulsi yang stabil. Namun, penambahan yang terlalu banyak dan partikel 
serat yang kurang kecil akan menyebabkan emulsi menjadi tidak stabil. ${ }^{22}$

Serat sebagian besar terkandung dalam sayur-sayuran, buah, serealia dan biji-bijian. PERKI (Perhimpunan Kardiologi Indonesia) menyarankan asupan serat 25-30 g/hari untuk kesehatan jantung dan pembuluh darah. ${ }^{4}$ Asupan serat larut air, seperti pektin dan gum diketahui dapat menurunkan kadar kolesterol LDL. ${ }^{3}$ Kadar serat tertinggi terdapat pada sosis tempe dengan penambahan bekatul beras merah $10 \%$, yaitu $9,138 \%$. Jadi, hanya $36,552 \%$ dari kebutuhan serat 25 g/hari yang dapat dipenuhi dari $100 \mathrm{~g}$ sosis dengan penambahan bekatul beras merah yang paling banyak.

Pengaruh Penambahan Bekatul Beras Merah terhadap Aktivitas Antioksidan Sosis Tempe

Aktivitas antioksidan tertinggi terdapat pada sosis tempe dengan penambahan bekatul beras merah $10 \%$, yaitu $13,28 \%$ dan aktivitas antioksidan terendah terdapat pada sosis tempe dengan penambahan bekatul beras merah $0 \%$, yaitu $7,97 \%$. Semakin banyak penambahan bekatul beras merah, maka aktivitas antioksidan sosis tempe cenderung meningkat. Peningkatan aktivitas antioksidan sosis tempe dengan penambahan bekatul beras merah dapat dilihat secara statistik dengan hasil yang bermakna.

Tempe mengandung suatu zat antioksidan dalam bentuk isoflavon. Isoflavon dalam tempe antara lain daidzein, glisitein, genistein, dan antioksidan faktor II $\left(6,7,4\right.$ trihidroksi isoflavon). ${ }^{17}$ Bekatul beras merah mengandung senyawa fenolik yaitu antosianin dan tokoferol (vitamin E). Antosianin merupakan salah satu jenis flavonoid yang diketahui mampu berperan sebagai antioksidan. ${ }^{11}$ Antosianin bersifat tidak stabil terhadap $\mathrm{pH}$, suhu, dan konsentrasi oksigen. Suhu tinggi pada saat pengolahan sosis, yaitu selama pengukusan memungkinkan terjadinya degradasi antosianin. ${ }^{23}$

Penurunan aktivitas antioksidan dalam bekatul beras merah terlihat dari pengujian sampel bekatul sebelum dan sesudah dioven. Aktivitas antioksidan bekatul sebelum dioven adalah $12,65 \%$, sedangkan bekatul yang sudah dioven mempunyai aktivitas antioksidan $11,27 \%$. Pemanasan dapat merusak kestablian antosianin sebagai salah satu senyawa fenol dalam bekatul sehingga bioaktivitasnya sebagai antioksidan menurun. ${ }^{24}$

Penelitian Zusana menyebutkan bahwa terdapat penurunan aktivitas antioksidan pada senyawa fenol seiring dengan adanya peningkatan suhu. Namun, setiap senyawa fenol memiliki penurunan yang berbeda-beda tergantung dari sifat senyawa tersebut dalam teroksidasi. $\alpha$-tokoferol memiliki sensitivitas pada suhu $80^{\circ} \mathrm{C}$ dan memiliki penurunan aktivitas antioksidan lebih lambat dibandingkan $\gamma$-tokoferol selama pemanasan. Senyawa fenol yang kurang mudah teroksidasi menunjukkan penurunan aktivitas antioksidan yang lebih lambat dibandingkan senyawa fenol yang mudah teroksidasi. Hal ini disebabkan karena kecepatan untuk memulai reaksi berhubungan dengan lebih cepat pula penggunaan antioksidan tersebut. Reaktivitas antioksidan melawan radikal bebas dikarakteristikan oleh ikatan $\mathrm{O}-\mathrm{H}$ dari senyawa fenol tersebut. Radikal bebas menerima elektron atau radikal hidrogen sehingga membentuk molekul yang stabil. ${ }^{24}$

\section{Pengaruh Penambahan Bekatul Beras Merah terhadap Kesukaan Sosis Tempe}

Warna merupakan karakter visual pertama yang dilihat oleh seorang panelis saat uji organoleptik. Ketertarikan panelis terhadap suatu produk dapat muncul setelah melihat warna, karena warna berkaitan dengan cita rasa suatu produk. Sosis tempe kontrol memiliki skor kesukaan warna tertinggi, yaitu 3,84 (suka), sedangkan sosis tempe dengan penambahan bekatul beras merah $10 \%$ memiliki skor kesukaan warna terendah, yaitu 2,09 (tidak suka).

Sosis tempe kontrol menghasilkan sosis tempe berwarna kuning cerah yang paling disukai panelis. Semakin banyak penambahan bekatul beras merah, warna sosis tempe akan semakin gelap dan cenderung tidak disukai. Hal ini disebabkan karena konsentrasi bekatul yang ditambahkan. Bekatul beras merah memiliki kandungan antosianin sebagai pigmen pemberi warna merah. ${ }^{11}$ Namun, terdapat reaksi Mailard, yaitu reaksi antara karbohidrat dengan gugus amina primer. Reaksi ini merupakan reaksi browning non enzimatis yang terjadi antara gula pereduksi dengan asam amino yang menghasilkan warna kecokelatan (melanoidin) pada bahan makanan ketika mengalami proses pemanasan. ${ }^{19} \mathrm{Hal}$ ini menyebabkan perubahan warna merah bekatul beras merah menjadi warna coklat setelah dioven pada suhu $121^{\circ} \mathrm{C}$ selama 15 menit.

Seluruh sosis tempe memiliki kesukaan aroma kategori netral. Kesukaan tertinggi panelis pada sosis tempe kontrol, dan kesukaan terendah pada sosis tempe dengan penambahan bekatul beras merah $10 \%$. Terdapat perbedaan yang bermakna di antara sosis dengan penambahan bekatul beras 
merah yang berbeda. Hal ini disebabkan karena adanya aroma langu dari tempe dan bekatul.

Aroma langu dapat disebabkan oleh tempe yang digunakan karena adanya aktivitas enzim lipoksigenase yang secara alami terdapat dalam kedelai. Enzim lipoksigenase dapat menghidrolisis asam lemak tak jenuh ganda dan menghasilkan senyawa-senyawa volatil penyebab aroma langu, khususnya etil fenil keton. ${ }^{17}$ Pada penelitian ini, sebelum dilakukan proses penggilingan, tempe yang digunakan dikukus terlebih dahulu pada suhu $70^{\circ} \mathrm{C}$ selama 15 menit. Hal ini dilakukan untuk menginaktivasi enzim lipoksigenase yang terdapat dalam tempe. Namun, proses ini hanya mengurangi $23 \%$ aktivitas enzim lipoksigenase,sehingga masih ada aktivitas enzim yang dapat bereaksi dengan lipid yang menyebabkan bau langu. ${ }^{25}$

Tekstur sosis tempe dipengaruhi oleh penambahan lemak dan bahan pengisi yaitu tapioka. Penambahan kedua bahan tersebut dapat menstabilkan emulsi sehingga terbentuk sosis yang kompak. ${ }^{6}$ Selain itu, proses pemasakan juga dapat meningkatkan kekompakan produk karena mampu mengurangi kadar air dalam produk. ${ }^{21}$

Seluruh sosis tempe memiliki kesukaan tekstur kategori netral. Sosis tempe kontrol memiliki tekstur yang mudah hancur. Semakin banyak penambahan bekatul beras merah, tekstur sosis tempe menjadi semakin padat. Hal ini sesuai dengan penelitian Choi et.al., yang menyebutkan bahwa penambahan bekatul dapat meningkatkan stabilitas emulsi karena sifat bekatul yang mampu menyerap air. ${ }^{12}$

Rasa merupakan atribut sensori yang penting dalam penentuan keputusan konsumen untuk menerima atau menolak suatu produk makanan. Walaupun suatu produk memiliki warna, aroma, dan tekstur yang baik, tetapi jika rasanya tidak enak maka produk tersebut akan ditolak. Rasa sosis tempe dengan penambahan bekatul beras merah memiliki kategori kesukaan dari suka hingga tidak suka.

Rasa sosis tempe dipengaruhi oleh besarnya penambahan bekatul beras merah yang digunakan. Sosis tempe dengan penambahan bekatul beras merah $10 \%$ memiliki skor kesukaan paling rendah, yaitu 2,54 (tidak suka). Hal ini disebabkan karena adanya rasa after taste berupa rasa pahit. Rasa pahit disebabkan karena adanya kandungan saponin dalam bekatul. Selain itu, after taste pahit dapat disebabkan oleh hidrolisis asam-asam amino yang terjadi pada reaksi Maillard, saat pengolahan sosis. ${ }^{9}$ Sumber utama rasa pahit adalah proses kerusakan lipid dan protein, oksidasi fosfatidilkolin, asam amino, dan peptida. ${ }^{26}$

Kontribusi Sosis Tempe dengan Penambahan Bekatul Beras Merah terhadap Kecukupan Gizi

Sosis tempe yang direkomendasikan adalah sosis tempe dengan penambahan bekatul beras merah 5\%. Seratus gram sosis tempe (3 buah) dapat menyumbang $16,39 \%$ kecukupan protein dari diet 2000 kkal. Kecukupan serat yang disumbangkan oleh $100 \mathrm{~g}$ sosis tempe adalah $33,65 \%$ dari kebutuhan 25 g/hari yang direkomendasikan oleh PERKI dengan aktivitas antioksidan sebesar $12,83 \%$. .Selain itu, dilihat dari mutu organoleptiknya, sosis ini berbeda dengan kontrol, tetapi temasuk dalam kategori tingkat kesukaan netral yang dapat diterima oleh panelis.

\section{SIMPULAN DAN SARAN \\ Simpulan}

1. Semakin banyak penambahan belatul beras merah, kandungan gizi sosis tempe semakin meningkat. Namun, tidak ada pengaruh penambahan bekatul beras merah terhadap kandungan gizi (kadar protein, lemak, karbohidrat dan serat) sosis tempe.

2. Ada pengaruh penambahan bekatul beras merah terhadap aktivitas antioksidan. Semakin banyak penambahan bekatul beras merah, aktivitas antioksidan sosis tempe semakin meningkat.

3. Semakin banyak penambahan bekatul beras merah, sosis tempe semakin tidak disukai oleh panelis. Secara statistik ada pengaruh penambahan bekatul beras merah terhadap kesukaan sosis tempe.

\section{Saran}

1. Sosis yang direkomendasikan adalah sosis tempe dengan penambahan bekatul beras merah $5 \%$.

2. Perlu ditambahkan pewarna makanan warna merah daging untuk memperbaiki warna sosis tempe.

3. Perlu ditambahkan emulsifier seperti Sodium Tripolyphospat (STTP) untuk membuat sosis dengan tekstur yang lebih baik.

4. Perlu penelitian lebih lanjut tentang pengaruh suhu dan masa penyimpanan terhadap kandungan gizi sosis tempe dengan penambahan bekatul beras merah.

\section{DAFTAR PUSTAKA}

1. Ari Yuniastuti. Gizi dan Kesehatan. Yogyakarta: Graha Ilmu; 2008. p. 95-102. 
2. World Health Organization. The Global Burden of Disease 2004 Update. Switzerland: WHO; 2008.p. 8-22.

3. Krummel DA. Medical Nutrition Therapy in Cardiovascular Disease. In: Mahan LK, Escottstump S. Krause's Food, Nutrition, and Diet Therapy 12th Edition. Philadelphia: WB Saunders Company; 2008. p. 64-833.

4. Nainggolan O dan Adimunca C. Diet Sehat dengan Serat. Cermin Dunia Kedokteran; 2005. p. 6-43.

5. Jonsen, G.D. Prospek dan Preferensi Masyarakat Terhadap Konsumsi Daging Sapi Olahan di Indonesia. Proceedings of The FGW Food Conference; 2004 6-7 Oktober; Jakarta; 2004.

6. Martin M, Julie Garden. The art and practice of sausage making. North Dakota: North Dakota State University Extension Service; 2004. p. 2-5.

7. Santoso. Teknologi Pengolahan Kedelai. Laboratorium Kimia Pangan Fakultas Pertanian Universitas Widyagama Malang. 2005. p. 30-33.

8. Sri Winarti. Makanan Fungsional. Yogyakarta: Graha Ilmu; 2010. p. 137-165.

9. Winarno. Kimia pangan dan gizi. Jakarta: PT Gramedia Pustaka Utama; 2002. p. 50-115.

10. Ridwan Rachmat dan Suismono. Teknologi Pengolahan Padi Terpadu dengan Pengerapan Sistem Manajemen Mutu. Yogyakarta: Badan Penelitian dan Pengembangan Pasca Panen Pertanian, 2007.

11. Tyagita Fitriana Dewi. Aktivitas Antioksidan, Kadar Total Fenol, Kadar Serat Pangan dan Kualitas Sensori Roti Tawar dengan Penambahan Bekatul dari Beras Merah dan Beras Hitam [SKRIPSI]. Surakarta: Universitas Sebelas Maret; 2011.

12. Choi YS, Choi JH, Han DJ, et. al. Effects of replacing pork back fat with vegetable oils and rice bran fiber on the quality of reduced-fat frankfurters. Meat Science. 2010; 84: 557-563.

13. Association of Analytical Chemist [AOAC] publisher.2005.Official methodes of analysis of the associationof official analytical chemist.Arlington:Virginia USA:The Association of Official Analytical Chemist,Inc.

14. Huang SC, Shiau CY, Liu TE, Chu CL, Hwang DF. Effects of rice bran on sensory and physicochemical properties of emulsified pork meatballs. Meat Science. 2005; 70: 613-619.

15. Rahmat Rukaman. Membuat Sosis: Daging Kelinci, Daging Ikan, Tempe Kedelai. Yogyakarta: Penerbit Kanisius; 2006. P. 21-25.

16. Khamsah SM, Akowah G \& Zhari I. Antioxidant activity and phenolic content of Orthosiphon stamineus benth from different geographical origin. J Sustainability Sci Mgmt. 2006. 1: 14-20.

17. Made Astawan. Sehat dengan hidangan kacang dan biji-bijian. Jakarta: Penebar Swadaya; 2009. p. 4 130.
18. Sri Sumarsih. Kontribusi Oleat, $\beta$-karoten, dan $\alpha$ tokoferol pada sifat hiperkolesterolemik Bekatul Beras Barlean (Beras Merah) [TESIS]. Yogyakarta: Universitas Gajah Mada; 1998.

19. Peter SM. Understanding Food Nutrition and Technology. United Stated of America: Thomson Learning; 2003. p. 120-148.

20. Eqbal MAD, Halimah AS, Aminah A, Zalifah MK. Fatty Acids Composition of Four Dofferent Vegetable Oils (Red Palm Olein, Palm Olein, Corn Oil and Coconut Oil) by Gas Chromatography. Intenational Conference on Chemistry and Chemical Engineering. 2011. IPCBEE vol. 14: p. 31-34.

21. Rosjarin Prabpree and Rungnaphar Pongsawatmanit. Effect of Tapioca Starch Concentration on Quality and Freeze-Thaw Stability of Fish Sausage. Kasetsart J. (Nat. Sci.) 45 : 314 - 324 (2011).

22. Yuni Harlinawati. Pembuatan Margarin Tinggi Serat Melalui Pemanfaatan Pektin dan Gum Arab Komersial [SKRIPSI]. Bogor: Institut Pertanian Bogor; 2002.

23. Umar Santoso. Antioksidan. Yogyakarta: Universitas Gajah Mada; 2006.

24. Zuzana Reblova. Effect of Temperature on the Antioxidant Activity of Phenolic Acids. Czech J. Food Sci. Vol. 30, 2012, No. 2: 171-177.

25. Savage, W. D., L. S. Wei, J. W. Sutherland, dan S. J. Schmidt. 1995. Biologically active component inactivation and protein insolublilization during heat processing of soybeans. Journal of Food Science. 69 (6) : $160-165$.

26. Evy Damayanthi, Liem Tong, Liliy Arbianto. Ricebran. Jakarta: Penebar Swadaya; 2007. 